\author{
Ewa Całus* \\ Uniwersytet Wrocławski
}

DOI: $10.19195 / 1733-5779.26 .1$

\title{
Bariery w dostępie do informacji gospodarczej dla konsumenta-seniora
}

JEL Classification: K2, K4

Slowa kluczowe: informacja gospodarcza, konsument-senior, obowiązki informacyjne, nieuczciwe praktyki rynkowe, wykluczenie cyfrowe

Keywords: commercial information, older consumer, digital exclusion, information duties, unfair commercial practices

Abstrakt: Seniorzy stanowią coraz liczniejszą grupę konsumentów. Bogata i różnorodna oferta rynkowa może podnosić standard życia seniorów, jednocześnie jednak zagrożeniem dla osób starszych jest brak odpowiedniej informacji o interesujących ich towarach i usługach. $Z$ reguły seniorzy nie zawsze są świadomymi konsumentami, znają swoje prawa i potrafią z nich korzystać. Dlatego tak istotne są zagadnienia związane z ograniczeniami konsumentów-seniorów w zakresie korzystania $\mathrm{z}$ informacji gospodarczej oraz nieuczciwych praktyk stosowanych przez przedsiębiorców w relacjach kontraktowych $\mathrm{z}$ tą grupą. Przedmiotowy artykuł ma na celu nakreślenie podstawowych problemów, jakie wiążą się z dostępem do informacji gospodarczej dla seniorów, począwszy od ograniczeń naturalnych związanych z wiekiem, jak ograniczona sprawność motoryczna, orientacja w regulacjach mających chronić słabszą stronę transakcji, znajomość procedury reklamacyjnej, aż po różnorodne zagadnienia związane z umowami zawieranymi w okolicznościach nietypowych — poza lokalem przedsiębiorstwa i na odległość. Ponadto poruszana będzie problematyka ,przeładowania” informacyjnego i współwystępującego „szumu” informacyjnego oraz wykluczenia cyfrowego jako elementów dodatkowo pogarszających sytuację konsumenta w podeszłym wieku w relacjach z profesjonalistą. W tym celu dokonana zostanie krytyczna analiza obowiązujących regulacji prawnych w zakresie dostępu do informacji konsumenckiej pod kątem jej dostosowania do potrzeb najstarszych uczestników gry rynkowej. Jednocześnie zostaną przedstawione propozycje rozwiązań, które mają niwelować występowanie tych negatywnych zjawisk.

* Opiekun naukowy (Scientific Tutor) — Robert Stefanicki

Studenckie Prace Prawnicze, Administratywistyczne i Ekonomiczne 26 


\title{
Barriers in access to commercial information for elder consumers
}

\begin{abstract}
Seniors constitute a more and more numerous consumer group. A wide and varied market offer can improve seniors' lives; however, on the other hand, the lack of proper information about the goods and services interesting for them poses a threat. Generally, seniors are not always self-aware consumers who are familiar with their rights and who can make use of them. Therefore, it is of vital importance to tackle issues connected with senior consumers' limitations regarding the area of the usage of commercial information and dishonest practices applied by entrepreneurs in contract relationships with this group. The substantive article aims to outline the basic problems which are concerned with seniors' access to economic information, starting with natural limitations resulting from age, such as limited motor capability, orientation in the provisions which are supposed to protect the weaker party of the transaction, familiarity with the complaint procedure, and ending with various issues connected with contracts concluded in atypical circumstances outside the business premises and remotely. Moreover, the subjects which will be tackled are information 'overload' and co-existing informational 'noise', as well as digital divide, as components which additionally deteriorate the elderly consumer's situation in relations with a professional. Simultaneously the propositions of solutions will be presented that are to level the occurrence of these negative phenomena.
\end{abstract}

\section{Wstęp}

Starzenie się społeczeństw państw członkowskich Unii Europejskiej, wynikające z malejącego przyrostu naturalnego oraz coraz lepszych usług medycznych, jest faktem. W związku z tym seniorzy stanowią sporą grupę konsumentów. Coraz więcej przedsiębiorców z różnych branż dedykuje swoje produkty i usługi właśnie osobom starszym - od firm farmaceutycznych i medycznych po banki. Ponadto niektórzy przedsiębiorcy zaczęli dostosowywać swoje produkty do potrzeb i możliwości seniorów (na przykład telefony komórkowe). Bogata i różnorodna oferta rynkowa może wpływać na rozwój jakości życia osób starszych. Drugą stroną medalu są natomiast nieuczciwe praktyki rynkowe stosowane przez przedsiębiorców, którzy próbują wykorzystać fakt, że seniorzy nie zawsze są zupełnie świadomymi konsumentami, znającymi swoje prawa i potrafiącymi z nich korzystać. Dlatego tak ważnym zagadnieniem jest rola informacji gospodarczej w zakresie umów zawieranych przez konsumentów trzeciego wieku. Niezwykle ważnym zagadnieniem związanym $\mathrm{z}$ dostępem do informacji dla konsumenta-seniora jest również zjawisko wykluczenia cyfrowego. Osoby starsze z reguły dużo rzadziej korzystają z Internetu, a co za tym idzie rzadko robią zakupy on-line. Może to stanowić istotny problem, ponieważ obecnie wielu producentów odsyła do informacji o produkcie zamieszczonych na stronach internetowych. Ponadto należy się liczyć z pewnymi naturalnymi ograniczeniami związanymi z wiekiem, takimi jak problemy ze wzrokiem, pogorszenie percepcji i możliwości nabywania nowych umiejętności. Zjawiska te wykorzystują przedsiębiorcy, na przykład przedstawiając seniorom do podpisu niekorzystne dla nich warunki umowne. Niniejszy artykuł poświęcony będzie problemom, z jakimi borykają się osoby starsze w dostępie do 
informacji gospodarczej, oraz nieuczciwym praktykom rynkowym, jakie stosują przedsiębiorcy w stosunku do seniorów. Ustawodawca europejski, a w ślad za nim krajowy, wprowadza z roku na rok coraz więcej regulacji mających zapewnić konsumentowi dostęp do rzetelnej i przejrzystej informacji dotyczącej produktów i usług na etapie przedkontraktowym. Mnogość informacji z założenia miała prowadzić do poprawienia pozycji konsumenta w relacjach z przedsiębiorcą, lecz zarazem potęguje zjawisko „przeładowania informacyjnego”, które może być szczególnie niebezpiecznie dla osób w podeszłym wieku. Na zakończenie niniejszej pracy postaram się przedstawić propozycję zmian mających ulepszyć pozycję konsumenta-seniora $\mathrm{w}$ relacjach kontraktowych z profesjonalistą $\mathrm{w}$ zakresie dostępu do informacji handlowej.

\section{Konsument-senior, przeciętny konsument, informacja gospodarcza}

$\mathrm{Na}$ wstępie konieczne wydaje się wyjaśnienie podstawowych dla niniejszych rozważań pojęć: konsument-senior, przeciętny konsument oraz informacja gospodarcza.

Biorąc pod uwagę terminologię stosowaną w odniesieniu do osób starszych jako konsumentów, można zauważyć, że często używanym pojęciem jest „starszy konsument". Używa się też innych określeń: konsument senioralny, trzeciego wieku, konsument dojrzały. Już na marginesie wypada wspomnieć, że różne są też poglądy na temat granicy wieku, od której możemy mówić o konsumentach-seniorach ${ }^{1}$. W ustawie $\mathrm{z}$ dnia 11 września 2015 roku o osobach starszych ${ }^{2}$ jako „starsza” została zdefiniowana osoba, która ukończyła 60. rok życia. Urząd Ochrony Konkurencji i Konsumentów w publikowanych materiałach, takich jak raporty, broszury informacyjne, artykuły, posługuje się różnym nazewnictwem — konsument trzeciego wieku, konsument-senior, osoba starsza. W wydanej pod patronatem Rzecznika Praw Obywatelskich publikacji Ustugi finansowe. Poradnik dla osób starszych najczęściej używanym terminem jest słowo „senior”’3. W samych nazwach i opisach ofert kierowanych przez przedsiębiorców do konsumentów najczęściej używanym określeniem także jest „,senior”4.

Zdefiniowanie pojęcia informacji wydaje się zadaniem trudnym głównie ze względu na jego wieloznaczność oraz odmienne postrzeganie w różnych dziedzinach nauki. W języku potocznym informacja pojmowana jest jako wiadomość,

${ }^{1} \mathrm{~K}$. Bałandynowicz-Panfil, Interdyscyplinarne dylematy granic starszego wieku - wstęp do rozważań nad wiekiem granicznym starszych konsumentów, „Acta Universitatis Lodziensis, Folia Oeconomica" 321 (3), 2016, s. 21-30.

2 Dz.U. z 2015 r., poz. 1705.

3 J. Mielczarek, Usługi finansowe. Poradnik dla osób starszych, Warszawa 2010, https://www. rpo.gov.pl/sites/default/files/BIULETYN_RPO_Materialy_nr_73.pdf (dostęp: 20.02.2017).

${ }^{4}$ K. Bałandynowicz-Panfil, op. cit., s. 28. 
pouczenie, powiadomienie o czymśs ${ }^{5}$. Pojęcie to wywodzi się z łaciny (informatio) i oznacza wyobrażenie, pojęcie, wyjaśnienie, podanie do wiadomości ${ }^{6}$. Bardzo szeroko definiuje informację M. Maciejewski jako „utrwalony w dowolny sposób (także w pamięci człowieka) komunikat (wiedza, świadomość) o jakimś fakcie"7.

Wiele regulacji prawnych odwołuje się do pojęcia informacji. Ustawodawca wyróżnia informację: finansową, publiczną, w ochronie zdrowia, gospodarczą, handlową, kryminalną, niejawną, informacje o środowisku ${ }^{8}$. W kontekście dostępu do informacji publicznej pojęcie informacji definiuje się przez odniesienie do podmiotów, które taką informacją dysponują — informacja jest to wiedza będąca w dyspozycji podmiotów zobowiązanych, a więc odnosząca się do ich działalności9 ${ }^{9}$.

Dla omawianych zagadnień najistotniejsze jest pojęcie informacji gospodarczej $i$ handlowej. Pojęcie informacji gospodarczej w prawie europejskim i orzecznictwie ETS jest rozumiane szeroko. Świadczy o tym definicja komunikacji handlowej zamieszczona w Zielonej Księdze Komisji Europejskiej z dnia 8 maja 1996 roku pt. Komunikacja handlowa w krajach Wspólnego rynku ${ }^{10}$. W myśl tej definicji komunikacja handlowa to wszelkie formy komunikacji, które mają na celu wspieranie sprzedaży towarów i usług bądź budowanie na rynku wyobrażenia o przedsiębiorstwie lub organizacji, w tym wszystkie formy marketingu bezpośredniego, sponsoringu, wspierania sprzedaży, włącznie z wykończeniem produktu i jego opakowaniem. Zgodnie z przytoczoną definicją wszystkie środki służące promocji i marketingowi bezpośredniemu, a także reklama powinny być traktowane jako źródło wiedzy o przedsiębiorcy, produkcie oraz warunkach zawierania i wykonania umowy ${ }^{11}$.

W dyrektywie 2000/31/WE ${ }^{12}$ posłużono się pojęciem commercial comunications, które można przetłumaczyć jako przekaz handlowy albo komunikacja handlowa. Przełożenie tego zwrotu jako informacji handlowej należy uznać za dość niefortunne, ponieważ w języku prawnym pojęcie to miało już utrwalone znaczenie. W tradycyjnym rozumieniu informacja handlowa pojmowana była jako

5 S. Skorupka, H. Anderska, Z. Łempicka, Mały słownik języka polskiego, Warszawa 1968, s. 235.

6 J. Sondel, Stownik łacińsko-polski dla prawników i historyków, Kraków 2009, s. 484.

7 M. Maciejewski, Prawo informacji - zagadnienia ogólne, [w:] Prawo informacji. Prawo do informacji, red. W. Góralczyk, Warszawa 2006, s. 31.

8 B. Pachucka-Smulska, Ochrona konsumenta w prawie polskim i Unii Europejskiej, Warszawa 2013, s. 38-39.

9 G. Skiba, Główne problemy prawa do informacji w świetle prawa i standardów międzynarodowych, europejskich $i$ wybranych państw Unii Europejskiej, Warszawa 2013, s. 15.

10 COM (1996) 389 final.

11 R. Stefanicki, Informacje jako środek ochrony słabszej strony umowy w prawie wspólnotowym, „Studia Prawnicze” 2008, nr 1, s. 75.

12 Dyrektywa 2000/31/WE Parlamentu Europejskiego i Rady z dnia 8 czerwca 2000 roku w sprawie niektórych aspektów prawnych usług społeczeństwa informacyjnego, w szczególności handlu elektronicznego w ramach rynku wewnętrznego (Dz.U. UE L z dnia 17 lipca 2000 r.). 
neutralny przekaz informacyjny, który jest związany z prowadzoną działalnością gospodarczą, lecz pozbawiony elementu zachęty do nabycia towaru lub usługi 13 . W doktrynie zasadniczo dokonuje się rozróżnienia pojęcia reklamy od informacji handlowej, ponieważ służą one innym celom. W obu przypadkach intencją jest dostarczanie informacji o produktach i usługach, z tym że reklama ma na celu przede wszystkim podniesienie poziomu sprzedaży, zaś informacja handlowa sensu stricto - dostarczyć informację o istniejących na rynku towarach i usługach, co ma pomóc konsumentowi przy podjęciu decyzji dotyczącej zakupu ${ }^{14}$.

Zgodnie z art. 2 pkt 2 ustawy o świadczeniu usług drogą elektroniczną ${ }^{15}$ informacja handlowa to każda informacja przeznaczona bezpośrednio lub pośrednio do promowania towarów, usług lub wizerunku przedsiębiorcy lub osoby wykonującej zawód, której prawo do wykonywania zawodu jest uzależnione od spełnienia wymagań określonych w odrębnych ustawach, z wyłączeniem informacji umożliwiającej porozumiewanie się za pomocą środków komunikacji elektronicznej z określoną osobą oraz informacji o towarach i usługach niesłużącej osiągnięciu efektu handlowego pożądanego przez podmiot, który zleca jej rozpowszechnianie, w szczególności bez wynagrodzenia lub innych korzyści od producentów, sprzedawców i świadczących usługi. Ustawodawca przyjmuje zatem wąskie rozumienie informacji handlowej, sprowadzające się głównie do kwestii promocji towarów i usług oferowanych przez przedsiębiorcę ${ }^{16}$.

Na potrzeby niniejszych rozważań należy zdefiniować informację handlową szeroko - jako wiedzę o przedmiocie świadczenia, która ma wpływ na proces decyzyjny konsumenta, a także wiedzę o jego kontrahencie.

Przy rozważaniach dotyczących znaczenia informacji gospodarczej dla konsumenta-seniora niezbędne jest przywołanie pojęcia konsumenta przeciętnego, które zostało wykreowane w oparciu o orzecznictwo Europejskiego Trybunału Sprawiedliwości (obecnie Trybunał Sprawiedliwości Unii Europejskiej). Dla ustalenia wzorca przeciętnego konsumenta, którym posługujemy się obecnie w prawie unijnym, ogromną wagę miało orzeczenie Komisja v. Niemcy ${ }^{17}$, w którym Trybunał po raz pierwszy posłużył się pojęciem przeciętnego konsumenta, oraz sprawa Mars ${ }^{18}$, w której wyszczególniono cechy, jakimi powinien się on charakteryzować. Duże

13 E. Traple, Prawo reklamy i promocji, Warszawa 2007, s. 643.

14 X. Konarski, Komentarz do ustawy o świadczeniu ustug droga elektroniczna, Warszawa 2004, s. 52.

15 Ustawa z dnia 18 lipca 2002 roku o świadczeniu usług drogą elektroniczną (Dz.U. z 2013 r., poz. 1422).

16 J. Gołaczyński, Ustawa o świadczeniu usług droga elektroniczną. Komentarz, Warszawa 2009, LEX, komentarz do art. 2.

17 Wyrok ETS z 22 maja 1992 roku w sprawie C-290/90, Komisja v. Niemcy, ECR 1992, s. I-3874.

18 Wyrok ETS z 6 lipca 1995 roku w sprawie C-470/93, Verein gegen Unwesen In Handel und Gewerbe Köln v. Mars GmbH, ECR 1995, s. I-1923. 
znaczenie odegrały orzeczenia Clinique ${ }^{19}$ czy Graffione ${ }^{20}$, w których Trybunał stwierdzil, że to, co wprowadza konsumentów w błąd w jednym państwie, niekoniecznie odniesie ten sam skutek w innym państwie. $Z$ kolei w sprawie Buet ${ }^{21}$ Trybunał zwrócił uwagę na konieczność objęcia szczególną ochroną konsumentów szczególnie podatnych na wprowadzanie w błąd i agresywne techniki sprzedaży. Wzorzec ustalony w orzecznictwie Trybunału znalazł wyraz w regulacjach unijnych, a mianowicie w dyrektywie 2005/29/WE o nieuczciwych praktykach handlowych ${ }^{22}$. Pojęcie przeciętnego konsumenta nie przybrało jednak formy definicji legalnej, lecz znalazło się w punkcie 18 preambuły dyrektywy, stanowiąc punkt odniesienia przy ocenie nieuczciwych praktyk handlowych. Polski ustawodawca, odmiennie od europejskiego, stworzył normatywny model przeciętnego konsumenta. W przepisach ustawy o przeciwdziałaniu nieuczciwym praktykom rynkowym ${ }^{23} \mathrm{w}$ art. 2 pkt 8 umieścił definicję legalną przeciętnego konsumenta, zgodnie z którą przeciętny konsument to taki, który jest dostatecznie dobrze poinformowany, uważny i ostrożny. Oceny dokonuje się z uwzględnieniem czynników społecznych, kulturowych, językowych i przynależności danego konsumenta do szczególnej grupy konsumentów, przez którą rozumie się dającą się jednoznacznie zidentyfikować grupę konsumentów szczególnie podatnych na oddziaływanie praktyki rynkowej lub na produkt, którego praktyka rynkowa dotyczy, ze względu na szczególne cechy, takie jak wiek, niepełnosprawność fizyczna lub umysłowa. Do grupy przeciętnych konsumentów zalicza się osoby, które ze względu na pewne cechy, takie jak wiek czy niepełnosprawność, różnią się od konsumenta typowego. Konsumenci wrażliwi z kolei nie mogą być traktowani jak statystyczni konsumenci — takie zachowanie jest uzasadnione, gdy dany produkt czy dana usługa są kierowane bezpośrednio do tej kategorii konsumentów. W odniesieniu do niektórych grup społecznych na przedsiębiorcy będą ciążyć dalsze obowiązki w zakresie zapewnienia uczciwości praktyki rynkowej - na przykład w przypadku dzieci czy właśnie osób starszych ${ }^{24}$. Przekładając to na obowiązek przekazania senio-

19 Wyrok ETS z 2 lutego 1994 roku w sprawie C-315/92, Verband Sozialer Wettbewerb v. Clinique Laboratoires SNC Lauder Cosmetics GmbH, ECR 1994, s. I-317.

20 Wyrok ETS z 26 listopada 1996 roku w sprawie C-313/94, F.Iii Graffione SNC v. Ditta Fransa, ECR 1996, s. I-06039.

21 Wyrok ETS z 16 maja 1989 roku w sprawie C-382/87, R. Buet i Educational Business Services (EBS) SARL v. Ministere Public, ECR 1989, s. 1235.

22 Dyrektywa 2005/29/WE Parlamentu Europejskiego i Rady z dnia 11 maja 2005 roku dotycząca nieuczciwych praktyk handlowych stosowanych przez przedsiębiorstwa wobec konsumentów na rynku wewnętrznym oraz zmieniająca dyrektywę Rady 84/450/EWG, dyrektywy 97/7/WE, 98/27/WE i 2002/65/WE Parlamentu Europejskiego i Rady oraz rozporządzenie (WE) nr 2006/2004 Parlamentu Europejskiego i Rady (Dz.Urz. UE L Nr 149, s. 22).

23 Ustawa z dnia 23 sierpnia 2007 roku o przeciwdziałaniu nieuczciwym praktykom rynkowym (Dz.U. z 2016 r., poz. 3).

24 A. Michalak, Ustawa o przeciwdziałaniu nieuczciwym praktykom rynkowym. Komentarz, Warszawa 2008, Legalis, komentarz do art. 2. 
rom określonych informacji na etapie przedkontraktowym, można wyszczególnić dwa rodzaje informacji, których podanie będzie konieczne. Po pierwsze, będą to informacje, których obowiązek podania wynika z przepisów szczególnych; po drugie - informacje, które należy przekazać konsumentowi w celu przedstawienia mu pełnego obrazu oferowanego produktu, a ilość tych informacji i sposób ich przekazu powinny być uzależnione między innymi od wieku danego konsumenta.

\section{Regulacje związane $z$ dostępem konsumenta do informacji gospodarczej}

Szczególna ochrona konsumenta postrzeganego w relacjach z przedsiębiorcą jako strona słabsza podyktowana jest przede wszystkim zjawiskiem asymetrii informacyjnej, co oznacza, że po stronie konsumenta przy zawieraniu umowy z przedsiębiorcą występuje deficyt informacji o przedmiocie i jakości świadczenia. Wynika to przede wszystkim ze znacznego stopnia specjalizacji przedsiębiorców trudniących się sprzedażą określonej kategorii produktów. Naturalne jest, że profesjonalista dokładnie zna oferowany produkt oraz wie, jak zachęcić do jego zakupu. Nie bez znaczenia pozostają zabiegi marketingowe stosowane przez przedsiębiorców w celu nakłonienia ludzi do zakupów. Dostrzegając to negatywne zjawisko, ustawodawca zdecydował się na szczególną regulację umów konsumenckich, która wykazuje wiele odmienności od ogólnego reżimu prawa umów. Jednym z przejawów tej szczególnej ochrony jest przyznanie konsumentowi prawa do informacji o przedmiocie i treści umowy na etapie przedkontraktowym. Skorelowane jest to z obowiązkami informacyjnymi przedsiębiorcy, których niewykonanie może powodować daleko idące konsekwencje prawne, na przykład obowiązek ponoszenia przez przedsiębiorcę kosztów, o których nie poinformował konsumenta przy zawieraniu umowy czy możliwość powołania się przez konsumenta na błąd lub podstęp, co skutkuje wzruszalnością umowy. Ochronę tę zapewniają przepisy kodeksu cywilnego, zwłaszcza część poświęcona zobowiązaniom umownym, oraz wiele ustaw okołokodeksowych przyjętych do polskiego porządku prawnego w związku z koniecznością implementacji unijnych dyrektyw. W rezultacie mamy w tej dziedzinie wiele ustaw dotyczących praw konsumenta, kredytu konsumenckiego, timeshare, usług turystycznych, nieuczciwych praktyk handlowych, które nakazują dostarczyć konsumentowi określone informacje na etapie przedumownym. Katalogi te mają charakter kazuistyczny, przybierając nieraz postać szczegółowych formularzy, których wzór jest najczęściej załącznikiem do dyrektywy (umowa timeshare, umowa o kredyt konsumencki). Można mówić także o pewnym rozproszeniu przepisów dotyczących informacji konsumenckiej, co jest związane ze stosowaniem często do umów konsumenckich regulacji innych niż typowo konsumenckie ${ }^{25}$. Jako przykład takiej regulacji można przywołać

25 E. Wojtaszek-Mik, Informacja przedumowna $w$ dyrektywie 2011/83/UE w sprawie praw konsumentów (problemy implementacyjne w prawie polskim), PPH kwiecień 2014, s. 30. 
ustawę z dnia 19 sierpnia 2011 roku o usługach płatniczych ${ }^{26}$ (obowiązki informacyjne $z$ art. 16-32a).

Ustawą o prawach konsumenta ${ }^{27}$ nałożono na przedsiębiorcę obowiązek udzielenia konsumentowi informacji zarówno w wypadku zawierania umowy sprzedaży w konwencjonalny sposób - w sklepie stacjonarnym, jak i przy zawieraniu umów poza lokalem przedsiębiorstwa (dom klienta, pokaz, wycieczka) oraz na odległość (przez Internet, telefon itp.). W tym drugim wypadku obowiązki informacyjne zostały określone znacznie szerzej — art. 12 ustawy o prawach konsumenta wskazuje na 21 obowiązków informacyjnych, jakie przedsiębiorca musi spełnić przy zawieraniu umowy z konsumentem. W wypadku sklepów internetowych przedsiębiorca musi także mieć na uwadze obowiązki wynikające z ustawy o świadczeniu usług drogą elektroniczną. W wypadku sklepów internetowych momentem, do którego wskazane informacje powinny być przekazane, jest złożenie przez konsumenta zamówienia. W przypadku umów zawieranych na odległość przedsiębiorca ma obowiązek udzielić informacji w sposób odpowiadający rodzajowi użytego środka porozumiewania się na odległość, w sposób czytelny i wyrażony prostym językiem. W każdym wypadku informacje udzielone przez sprzedawcę powinny być jasne, zrozumiałe i niewprowadzające w błąd, udzielone w języku polskim (art. 546 ${ }^{1}$ k.c.). Obowiązek używania języka polskiego w obrocie konsumenckim przewiduje w art. 7 ustawa o języku polskim ${ }^{28}$. Dotyczy to w szczególności nazewnictwa towarów i usług, ofert, warunków gwarancji, faktur, rachunków i pokwitowań, jak również ostrzeżeń i informacji dla konsumentów, wymaganych na podstawie innych przepisów, instrukcji obsługi oraz informacji o właściwościach towarów i usług. Obcojęzyczne opisy towarów i usług oraz obcojęzyczne oferty, ostrzeżenia i informacje dla konsumentów, wymagane na podstawie innych przepisów w tym zakresie, muszą być sporządzone jednocześnie w polskiej wersji językowej. Produkty żywnościowe często oprócz umieszczanych na opakowaniu informacji w języku polskim zawierają informacje również $\mathrm{w}$ innych językach. Wielość informacji znajdujących się nieraz na bardzo małej powierzchni opakowania sprawia, że są one nieczytelne dla przeciętnego konsumenta, tym bardziej dla seniora. Co do produktów paczkowanych wymogi w zakresie określonych informacji znajdujących się na opakowaniach określa ustawa o towarach paczkowanych ${ }^{29}$. Rozporządzenie wykonawcze do tej ustawy określa nawet minimalną wielkość cyfr i liter znajdujących się na takich opakowaniach w zależności od jego wielkości (podawana $\mathrm{w} \mathrm{mm})^{30}$. Powszechnie

26 Dz.U. z 2016 r., poz. 1572.

27 Ustawa z dnia 30 maja 2015 roku o prawach konsumenta (Dz.U. z 2014 r., poz. 827).

28 Ustawa z dnia 7 października 1999 roku o języku polskim (Dz.U. Nr 43, poz. 224).

29 Ustawa z dnia 7 maja 2009 roku o towarach paczkowanych (Dz.U. z 2015 r., poz. 1161).

30 Mowa tu o Rozporządzeniu Ministra Gospodarki w sprawie szczegółowych wymagań dotyczących oznakowań towarów paczkowanych z dnia 20 lipca 2009 roku (Dz.U. Nr 122, poz. 1010). 
wiadomo, że wraz z wiekiem ostrość i komfort widzenia pogarszają się, dlatego mała czcionka na opakowaniu produktu może być dla osoby w podeszłym wieku bardzo problematyczna.

Problem małego druku dotyczy nie tylko opakowań, lecz także często konstrukcji samych umów konsumenckich. W wypadku usług finansowych czy umów ubezpieczenia umowy pomiędzy klientem a profesjonalistą mają niejednokrotnie obszerną postać. Wykorzystuje się małą czcionkę jako element, który ma zniechęcić klienta do zapoznawania się ze szczegółowymi informacjami o mniej korzystnych elementach oferty. Konsument najczęściej się z takimi informacjami nie zapozna i będzie narażony na negatywne konsekwencje postanowień umowy pisanych „drobnym maczkiem”.

Podsumowując, należy stwierdzić, że ze względu na mnogość regulacji dotyczących informacji handlowej, jaką przedsiębiorca powinien przekazać klientowi na etapie przedkontraktowym, konsument-senior „,bombardowany” dużą liczbą informacji działa często czysto intuicyjnie. Dyskusyjne jest bowiem, czy informacja konsumencka powinna być tak drobiazgowa ${ }^{31}$. Zjawisko tak zwanego szumu informacyjnego nie jest korzystne dla klienta przy podejmowaniu decyzji o przyjęciu oferty przedsiębiorcy, może zaś powodować konsternację i efekt odwrotny od zamierzonego. Obszerny tekst zniechęca do szczegółowego zapoznania się z prezentowaną informacją o produkcie i zazwyczaj konsument dokonuje tego w sposób pobieżny, czemu sprzyja niejednokrotnie wizualny sposób przekazu informacji (mała czcionka, zbyt duża liczba informacji na małej powierzchni opakowania produktu).

\section{Ograniczenia związane z dostępem seniorów do informacji handlowej}

Osoby w podeszłym wieku ze względu na naturalne ograniczenia w zakresie dostępu do informacji handlowej są w gorszej sytuacji niż osoby młodsze. Niestety tempo przetwarzania informacji w układzie nerwowym, będące podstawą działania ludzkiego umysłu, maleje wraz z wiekiem. Potęguje to fakt, że wśród seniorów niższy jest udział osób z wyższym wykształceniem. Dopiero ostatnich kilkanaście lat było okresem ,boomu edukacyjnego” w Polsce. W tym czasie rzeczywiście nastąpił wyraźny wzrost popularności kształcenia na poziomie wyższym oraz istotnie zmniejszył się odsetek osób, które zakończyły edukację na poziomie szkoły podstawowej. Najliczniejszą grupę wśród ludności w wieku 65

31 M. Grochowski, Obowiazki informacyjne w umowach z udziałem konsumentów a nadmierny formalizm prawa, [w:] Kierunki rozwoju europejskiego prawa prywatnego. Wpływ europejskiego prawa konsumenckiego na prawo krajowe, red. M. Jagielska, E Rottt-Pietrzyk, A. Wiewiórkowska-Domagalska, Warszawa 2012, s. 187-201. 
i więcej lat stanowią osoby $z$ wykształceniem podstawowym ${ }^{32}$. Ograniczenia w dostępie do informacji z jednej strony wynikają z tego, że wiele umów i ulotek informacyjnych, broszur napisano językiem trudnym do zrozumienia dla osób starszych. Z drugiej strony przedsiębiorcy coraz częściej odsyłają do Internetu jako źródła szczegółowych informacji, co dla sporej części seniorów jest dużą barierą, o czym jeszcze będzie mowa w dalszej części pracy. Wśród osób starszych zauważa się również nieznajomość symboli bezpieczeństwa oraz symboli i nagród jakościowych, co sprawia, że przy wyborze produktu nie mogą oni uwzględnić tych ważnych czynników - na przykład znak jakości Q, przyznawany przez Polskie Centrum Badań i Certyfikacji (PCBC), który dla konsumentów jest gwarancją, że wyrób jest bezpieczny dla zdrowia i środowiska, a także smaczny. Produkt, który uzyska certyfikat uprawniający do oznaczenia go znakiem jakości Q, powinien spełniać wymagania wyższe niż przeciętne, regulowane podstawowymi normami. Kolejnym przykładem jest symbol CE, utożsamiany z gwarancją jakości i bezpieczeństwa użytkowania danego produktu; umieszczany jest obowiązkowo wyłącznie na wybranych grupach wyrobów, na przykład elektronice, zabawkach, które mogą bezpośrednio stwarzać zagrożenie dla zdrowia lub życia konsumentów. Oznakowanie CE symbolizuje zgodność wyrobu z odpowiednimi wymaganiami UE nałożonymi na producentów. Oznacza, że produkt jest bezpieczny w użytkowaniu i został wyposażony we wszelkie, niezbędne zabezpieczenia ${ }^{33}$.

Jak wynika z raportu UOKiK z 2009 roku, konsumenci trzeciego wieku są mniej świadomi swych praw, rzadziej niż pozostałe grupy wiekowe zgłaszają reklamacje. Osoby starsze wykazują się też większą ustępliwością w walce o swe prawa. Innym aspektem omawianego zagadnienia jest lekceważenie osób starszych przez przedsiębiorców w próbach dochodzenia uprawnień bądź utwierdzanie ich w przekonaniu, iż wada towaru powstała $z$ winy nabywcy lub wskutek normalnego zużycia się produktu. Często zatem problem leży nie w samych przepisach, lecz w praktykach stosowanych przez przedsiębiorców, którzy próbują wprowadzać seniorów w błąd co do obowiązków producenta/sprzedawcy, korzystając $\mathrm{z}$ ich nieznajomości prawa. Wspomniany utrudniony dostęp do informacji w połączeniu z częstym przekonaniem o tak zwanej uczciwości kupieckiej sprawia, że osoby starsze przejawiają wyższy poziom zaufania do kontrahentów oraz wiarę w umowę ustną i ustne przekazywane zapewnienia o właściwościach dobra i usługi czy wymogach związanych z procesem reklamacyjnym.

32 Opracowanie GUS, Sytuacja demograficzna osób starszych i konsekwencje starzenia się ludności Polski w świetle prognozy na lata 2014-2050, Warszawa 2014, s. 9, http://seniorzy.mcps. com.pl/sites/default/files/Sytuacja_demograficzna.pdf(dostęp: 13.01.2017).

33 P. Szukalski, Obszary zagrożenia praw osób starszych na rynku dóbr i ustug konsumpcyjnych, [w:] BIULETYN RPO materiaty. Stan przestrzegania praw osób starszych w Polsce - analiza i rekomendacje działań, red. B. Szatur-Jaworska, Warszawa 2008, s. 127. 


\section{Problemy w zakresie informacji gospodarczej przy umowach zawieranych na odległość i poza lokalem przedsiębiorstwa}

Kolejnym zagadnieniem istotnym z punktu widzenia osób starszych są zagrożenia związane z umowami zawieranymi poza lokalem przedsiębiorstwa. Normatywna regulacja szczególnej ochrony konsumenta w przypadku umów zawieranych poza lokalem przedsiębiorstwa związana jest niejako z zaskoczeniem towarzyszącym przy tego typu transakcjach ${ }^{34}$. Konsument nie ma możliwości przemyślenia propozycji zawarcia umowy, porównania innych, konkurencyjnych ofert oraz cen poszczególnych produktów. Szczególnie podatne na różnorodne zabiegi marketingowe, związane z zawieraniem umów na odległość, są właśnie osoby starsze, mniej świadome otaczających ich zagrożeń, ale za to bardziej ufne, przekonane o wspomnianej kupieckiej uczciwości, dysponujące zazwyczaj większą ilością czasu. Do zagrożeń związanych z transakcjami zawieranymi w domu konsumenta, w miejscu jego pracy, przy okazji różnego rodzaju wycieczek zalicza się też niedostateczną wiedzę na temat przedsiębiorcy, a tym samym jakości oferowanych przez niego produktów ${ }^{35}$. W wypadku tego typu transakcji ludzie działają często pod wpływem emocji. Nie sposób nie wspomnieć o różnego rodzaju prezentacjach i pokazach, podczas których starsze osoby często ulegają namowom i podpisują umowy, z których wcale nie są później zadowolone. Praktyka taka polega na tym, że dana firma organizuje prezentację swoich produktów, połączoną często z bezpłatnym posiłkiem, prezentem dla każdego uczestnika czy nawet wycieczką. Następnie w czasie pokazu demonstrowane są możliwości prezentowanych urządzeń, a później zachęca się przybyłych do ich zakupu. $\mathrm{W}$ takich pokazach uczestniczą głównie osoby starsze, ponieważ mają one więcej wolnego czasu i łatwiej dają się namówić na udział w prezentacji. Po pokazie uczestnik zachęcany jest do zakupu produktów argumentem, że to ostatnie dni tak niskiej ceny. Pokusa jest tym większa, że jeśli podczas takiego spotkania klient nie dysponuje gotówką, na miejscu ma do dyspozycji przedstawiciela pośrednika finansowego lub banku, który od ręki udzieli pożyczki. Często senior dopiero w domu orientuje się, że właśnie podpisał umowę kredytową, a kwota, którą wziął za całkowity koszt produktów, jest jedynie pierwszą ratą. Ewentualna rezygnacja z zakupu w ciągu 14-dniowego terminu na odstąpienie od umowy jako zawartej poza lokalem przedsiębiorstwa dotyczyć będzie dwóch umów - umowy sprzedaży i umowy kredytowej, z czego konsumenci nie zawsze zdają sobie sprawę.

Podobnie rzecz ma się w wypadku zawierania umów o dostarczenie energii elektrycznej bądź umów zawieranych z przedsiębiorcą oferującym usługi telekomunikacyjne. Senior, skuszony wizją mniejszych rachunków za prąd lub telefon

34 M. Hładyszewski, Umowy zawierane poza lokalem przedsiębiorstwa, [w:] Europejskie prawo konsumenckie a prawo polskie, red. E. Nowińska, P. Cybula, Kraków 2005, s. 107.

35 P. Mikłaszewicz, Obowiązi informacyjne w umowach z udziatem konsumentów na tle prawa Unii Europejskiej, Warszawa 2008, s. 247-248. 
stacjonarny, podpisuje umowę, nie zdając sobie sprawy z tego, że umowa dotyczy jedynie na przykład dostarczania energii. Zdezorientowany konsument otrzymuje nagle dwa rachunki - jeden od podmiotu udostępniającego sieci przesyłowe, drugi od przedsiębiorcy dostarczającego energię, które łącznie przekraczają wysokość dotychczasowych, comiesięcznych zobowiązań za prąd. Zazwyczaj jest już wówczas za późno, aby skorzystać z prawa odstąpienia od umowy zawartej poza lokalem przedsiębiorstwa (do zawarcia takich umów dochodzi zazwyczaj w domu konsumenta), wypowiedzenie umowy związane jest zaś z koniecznością zapłaty ogromnej kary umownej, która przekracza możliwości finansowe przeciętnego seniora.

W kwestii umów zawieranych na odległość i poza lokalem przedsiębiorstwa znane były także przypadki, gdy konsumenci celowo byli wprowadzani w błąd co do tożsamości przedsiębiorcy oferującego towar lub usługi. Najczęściej owo wprowadzenie w błąd wiązało się z posługiwaniem się nazwą/firmą łudząco przypominającą nazwę/firmę podmiotu o ugruntowanej pozycji na rynku ${ }^{36}$.

O osobach starszych często mówi się w kontekście wykluczenia cyfrowego, jest to bowiem grupa, która w najmniejszym stopniu korzysta z nowoczesnych technologii. Wynika to przede wszystkim z występowania barier o charakterze edukacyjnym - osoby starsze często nie wiedzą, jak korzystać z komputera i Internetu, nie posiadają komputera, a także nie odczuwają potrzeby korzystania z niego. To wszystko sprawia, że seniorzy w zakresie dostępu do informacji handlowej znajdują się w gorszej sytuacji niż młodsze pokolenie. Należy także zwrócić uwagę na rosnące znaczenie nowych technologii na rynku dóbr konsumpcyjnych i wzrost roli handlu elektronicznego. Osoby starsze stanowią najmniejszą grupę spośród konsumentów dokonujących zakupów on-line, co jest istotne w związku z coraz bardziej znaczącym udziałem ofert dostępnych wyłącznie drogą elektroniczną. Ten kanał sprzedaży dla konsumenta jest dużo wygodniejszy, często tańszy, szybszy, umożliwiający błyskawiczne porównanie ofert różnych przedsiębiorców oraz dostawę towaru wprost pod drzwi klienta. Nierzadko przedsiębiorcy zdają się rezygnować z tradycyjnych form dostarczania informacji, odsyłając do regulaminów dostępnych na stronie internetowej bądź informacji zamieszczonych

36 W 2015 roku głośno było o spółce Polska Telefonia Stacjonarna, która wcześniej nazywała się „Telekomunikacja Dzień Dobry”. Konsultanci przedstawiali się słowami „Telekomunikacja Dzień Dobry", budząc w ten sposób zaufanie rozmówcy (wszyscy myśleli, że dzwoni przedstawiciel Telekomunikacji Polskiej i po prostu grzecznie się wita) i skutecznie nakłaniając go do podpisania nowej niekorzystnej umowy. Do klienta po jakimś czasie przyjeżdżał kurier z umową wówczas zakrywano logo firmy, podsuwano szybko papiery do podpisania, a kopię umowy obiecywano przesłać pocztą. Grupę docelową stanowiły często osoby starsze, którym słowo „telekomunikacja" kojarzy się jednoznacznie, a które mamione możliwością obniżenia abonamentu podpisywały umowę, nie zapoznając się wcześniej z jej treścią. Tak wprowadzeni w błąd klienci orientowali się o treści tej umowy wraz z doręczeniem im pierwszej faktury, która przychodziła, gdy było już za późno na odstąpienie od umowy. Zerwanie umowy z nowym operatorem obarczone było wysoką karą umowną. 
przy opisie produktu w sklepie internetowym. Dostęp do Internetu stanowi zatem obecnie nie tylko ułatwienie, lecz niekiedy wręcz warunek konieczny pełnego uczestnictwa w życiu społecznym, kulturalnym i zawodowym.

\section{Propozycje rozwiązań mających niwelować opisane zjawiska}

W zakresie informacji gospodarczej przeznaczonej dla konsumentów istnieje w prawie polskim wiele regulacji szczególnych. Sposób regulowania obowiązków informacyjnych w prawie konsumenckim prowadzi do wielu negatywnych następstw, które dotyczą zarówno konsumentów, jak i podmiotów profesjonalnych. Niejednokrotnie przedsiębiorcy muszą bardzo uważnie podchodzić do wypełniania obowiązków informacyjnych nałożonych przez ustawodawcę w celu uniknięcia wszelkich możliwych negatywnych konsekwencji związanych z ich niedopełnieniem. W wielu wypadkach kazuistyczny sposób regulowania obowiązków informacyjnych pod znakiem zapytania stawia realizację celu, jakiemu miały one służyć, a więc poprawę pozycji kontraktowej konsumenta w relacjach z przedsiębiorcą. Jest wręcz odwrotnie — zbyt duża liczba informacji może prowadzić do konsternacji, pobieżnego zapoznawania się z przedstawionymi informacjami bądź rezygnacji z przeglądania wielostronicowych regulaminów czy ogólnych warunków umów. Nie jest jednak możliwe narzucenie przedsiębiorcy obowiązku zapewnienia, że konsument zapoznał się z przedstawionymi mu informacjami, a tym bardziej, że zrozumiał on ich treść ${ }^{37}$.

Wśród przepisów dotyczących informacji gospodarczej brakuje norm szczególnych, które odnosiłyby się do konsumentów-seniorów, które odpowiadałyby na problemy, z jakimi się oni borykają. Jednocześnie jednak wprowadzenie regulacji specjalnych, dedykowanych stricte osobom starszym, może spotkać się z krytyką związaną z nadmiernym uprzywilejowaniem tej grupy. Pośrednio do tego problemu odnosi się ustawa o przeciwdziałaniu nieuczciwym praktykom rynkowym, która w art. 2 pkt 8 definiuje pojęcie przeciętnego konsumenta, co ma kluczowe znaczenie przy ocenie nieuczciwych praktyk rynkowych. Na podstawie tej definicji należy przyjąć, że w wypadku niektórych grup społecznych na przedsiębiorcy będą ciążyć dalej idące obowiązki w zakresie zapewnienia uczciwości praktyki rynkowej. Jednym z kryteriów wyodrębnienia takiej grupy jest wiek, co daje asumpt do stwierdzenia, że niedostarczenie odpowiedniej liczby informacji na etapie przedkontraktowym, uwzględniającej w tym zakresie wszelkie potrzeby osób starszych, będzie narażało przedsiębiorcę na zarzut dopuszczenia się nieuczciwej praktyki rynkowej i możliwość wystąpienia przez konsumenta z roszczeniami przewidzianymi w art. 12 ustawy o przeciwdziałaniu nieuczciwym

37 A. Wiewiórska-Domagalska, Obowiązi informacyjne w prawie Unii Europejskiej i braki w zakresie ich implementacji do prawa polskiego, dodatek do MoPr. 2013, nr 21, s. 4. 
praktykom rynkowym ${ }^{38}$. Ponadto należy mieć na uwadze motyw 34 dyrektywy 2011/83/UE ${ }^{39}$, zgodnie z którym przedsiębiorca powinien udzielić konsumentowi jasnych i wyczerpujących informacji zanim konsument zostanie związany umową zawieraną na odległość lub umową zawieraną poza lokalem przedsiębiorstwa, umową inną niż umowa zawierana na odległość lub umowa zawierana poza lokalem przedsiębiorstwa lub jakąkolwiek ofertą w tym zakresie. Udzielając takich informacji, przedsiębiorca powinien uwzględniać szczególne potrzeby szczególnie wrażliwych konsumentów: ich niepełnosprawność umysłową, fizyczną lub psychiczną, wiek lub łatwowierność, w sposób, który powinien był, racjonalnie oczekując, przewidzieć. W ustawie o prawach konsumenta nie znalazł się normatywny odpowiednik opisanej regulacji. Niemniej jednak przytoczony motyw dyrektywy konsumenckiej powinien dla przedsiębiorców stanowić wskazówkę interpretacyjną odnośnie do uwzględnienia szczególnych wymagań w zakresie informacji handlowej przy formułowaniu ofert przeznaczonych dla przedstawicieli szczególnie wrażliwych grup konsumentów.

Jednym z rozwiązań omawianego problemu może być wprowadzenie norm o charakterze ogólnym, nakładających — na wzór normy wyrażonej w art. 2.201 Zasad Acquis ${ }^{40}$ - na drugą stronę obowiązek przekazania informacji dotyczącej dóbr i usług, jakich kontrahent może rozsądnie oczekiwać w zakresie poziomu jakości oraz wykonania, które są normalne w danych okolicznościach. Oznacza to, iż każdorazowo należy oceniać, czym są owe rozsądne oczekiwania, a będzie to zależne od adresata opisywanego obowiązku. Wszelkie informacje odbiegające od zwykłego poziomu jakości lub wykonania zobowiązania, które miałyby prowadzić do niezgodności towaru/usługi z umową, podlegają zatem ujawnieniu.

38 Zgodnie z art. 12 ust. 1 u.p.n.p.r. ,w razie dokonania nieuczciwej praktyki rynkowej konsument, którego interes został zagrożony lub naruszony, może żądać:

1) zaniechania tej praktyki;

2) usunięcia skutków tej praktyki;

3) złożenia jednokrotnego lub wielokrotnego oświadczenia odpowiedniej treści i w odpowiedniej formie;

4) naprawienia wyrządzonej szkody na zasadach ogólnych, w szczególności żądania unieważnienia umowy z obowiązkiem wzajemnego zwrotu świadczeń oraz zwrotu przez przedsiębiorcę kosztów związanych z nabyciem produktu;

5) zasądzenia odpowiedniej sumy pieniężnej na określony cel społeczny związany ze wspieraniem kultury polskiej, ochroną dziedzictwa narodowego lub ochroną konsumentów".

39 Dyrektywa Parlamentu Europejskiego i Rady 2011/83/UE z dnia 25 października 2011 roku w sprawie praw konsumentów, zmieniająca dyrektywę Rady 93/13/EWG i dyrektywę 1999/44/WE Parlamentu Europejskiego i Rady oraz uchylająca dyrektywę Rady 85/577/EWG i dyrektywę 97/7/ WE Parlamentu Europejskiego i Rady (Dz.U.UE L z dnia 22 listopada 2011 r.).

40 Principles of the Existing EC Contract Law (Acquis Principles). Contract I. Precontractual Obligations, Conclusion of Contract, Unfair Terms prepared by Research Group on the Existing EC Private Law (Acquis Group), Munich 2007; polski przekład autorstwa M. Pecyny ukazał się w KPP 2008, nr 3, s. 809 n. 
Co istotne, tego typu regulacja nakładałaby na przedsiębiorcę obowiązek dostosowania rodzaju informacji do adresata swojej oferty. Zakres informacji interesujących osoby w wieku 30 lat może być bowiem różny od tego, którego oczekują osoby po sześćdziesiątym roku życia. Wprowadzenie takiej regulacji sprawi, że przedsiębiorca przy formułowaniu komunikatów handlowych skierowanych do konsumenta powinien upewnić się, że zawiera on wszystkie relewantne dla niego informacje.

Drugim z problemów, chyba najtrudniejszym do rozwiązania, jest konieczność zmiany nastawiania samych konsumentów. Udzielenie informacji (nawet najbardziej precyzyjnej) nie może zostać uznane za wystarczające, aby zapewnić efektywne funkcjonowanie norm, które miały służyć ochronie konsumenta. Konieczne jest podjęcie działań, które zainicjują zaangażowanie konsumentów w system ochrony przez informację, a tym samym jego większą efektywność. Powstaje zatem pytanie, co zrobić, aby zachęcić konsumenta do zapoznania się z informacjami przedstawionymi mu przez przedsiębiorcę przed zawarciem umowy, zwłaszcza w stosunku do konsumentów, w których wypadku ,zalew informacyjny" wydaje się najbardziej dotkliwy. Z pewnością niezbędne jest ograniczenie opisanego zjawiska „szumu informacyjnego” przez ograniczenie liczby informacji prezentowanych na opakowaniach produktów oraz umieszczenia odpowiedniej wielkości napisów na opakowaniach. Ponadto większość informacji dotyczących sytuacji prawnej konsumenta powinna być w prosty sposób dla niego osiągalna. W wypadku konsumentów trzeciego wieku, którzy częściej dokonują zakupów w sklepach stacjonarnych niż zakupów on-line, warto rozważyć umieszczanie „rozpiski” najważniejszych uprawnień przysługujących konsumentowi w widocznym miejscu w sklepie stacjonarnym/stoisku sprzedawcy. W tym miejscu należy przypomnieć o nieobowiązującym już rozporządzeniu Rady Ministrów z dnia 30 maja 1995 roku w sprawie szczegółowych warunków zawierania i wykonywania umów sprzedaży rzeczy ruchomych z udziałem konsumentów ${ }^{41}$, które nakładało na sprzedawcę obowiązek wywieszania w sklepie informacji na temat przysługujących konsumentowi uprawnień ${ }^{42}$. Ten akt prawny miał bezsprzecznie pozytywny wpływ na kształtowanie świadomości konsumentów w zakresie przysługujących im uprawnień.

Niewątpliwie istnieje także potrzeba prowadzenia różnego rodzaju kampanii społecznych czy szkoleń dedykowanych konsumentom trzeciego wieku, w trakcie

41 Dz.U. z 1995 r. Nr 64, poz. 328.

42 Zgodnie z $§ 26$ przywołanego rozporządzenia sprzedawca był obowiązany podać tekst niniejszego rozporządzenia do wiadomości konsumentów w każdym punkcie sprzedaży, przez umieszczenie go w miejscu swobodnie dla nich dostępnym. Ponadto w punktach prowadzących sprzedaż towarów żywnościowych powinny być w taki sam sposób podane do wiadomości konsumentów terminy zgłaszania reklamacji tych towarów. W punkcie sprzedaży należało umieścić na widocznym dla konsumenta miejscu ogłoszenie zawierające adres i telefon Państwowej Inspekcji Handlowej. 
których byłyby prezentowane podstawowe zagadnienia związane z reklamacją towarów i usług, gwarancją, zawieraniem umowy, usługami finansowymi czy sprzedażą na odległość bądź poza lokalem przedsiębiorstwa oraz podstawowych zagrożeń, na które narażeni są seniorzy w kontaktach z nieuczciwymi przedsiębiorcami, zwłaszcza przy tak zwanej sprzedaży bezpośredniej. Istnieje zatem potrzeba prowadzenia akcji edukacyjnych, takich jakie UOKiK zorganizował w 2011 roku, kiedy w całej Polsce dla konsumentów w wieku 60+ przeprowadzono szkolenia, zapoznając seniorów z ich prawami ${ }^{43}$. Popularność uniwersytetów trzeciego wieku pokazuje też, że seniorzy chętnie się uczą, a tego typu akcje społeczne mogą przynieść pożądany efekt.

Niewątpliwie należy przeciwdziałać zjawisku wykluczenia cyfrowego seniorów. Przede wszystkim zaś zakazane powinno być umieszczenie ważnych dla klientów informacji wyłącznie w Internecie. Nie można jednak na tym poprzestać i należy tworzyć warunki, które będą sprzyjać korzystaniu z Internetu i innych urządzeń, na przykład smartfonów, przez osoby starsze. Konieczne jest uświadomienie seniorom, jak Internet i inne technologie informacyjno-komunikacyjne mogą poprawiać ich życie, choćby poprzez możliwość korzystania z bankowości internetowej, zarejestrowanie się on-line na wizytę u lekarza, możliwość częstszych kontaktów z mieszkającą daleko rodziną czy też korzystania z e-booków z wielkością czcionki dopasowaną do indywidualnych potrzeb każdego seniora. Nie bez znaczenia będzie tu konieczność dostosowania sprzętu, oprogramowania oraz samego layoutu witryn sklepów internetowych do potrzeb konsumentów-seniorów.

\section{Podsumowanie}

Jak wynika z zaprezentowanych rozważań, konsumenci-seniorzy w zakresie dostępu do informacji gospodarczej znajdują się w gorszym położeniu niż młodsi konsumenci. Obecna konstrukcja obowiązków informacyjnych na gruncie ustaw konsumenckich wcale tej sytuacji nie poprawia. Konieczna jest zatem zmiana techniki legislacyjnej w zakresie regulacji obowiązków informacyjnych poprzez wprowadzenie norm ogólnych jako przeciwwagi dla kazuistycznych regulacji. Niezbędnym jest też podjęcie działań mających na celu zaangażowanie seniorów w system ochrony przez informację oraz zwiększenie świadomości konsumenckiej w zakresie przysługujących im uprawnień. Ulepszenie dostępu do informacji gospodarczej musi być także skorelowane z przeciwdziałaniem zjawisku wykluczenia cyfrowego seniorów, gdyż Internet jest w dzisiejszych czasach nieodzownym medium przekazu informacji o towarach i usługach, a także coraz częściej miejscem dokonywania zakupów. Poprawienie sytuacji osób starszych

43 Kampania była prowadzona pod hasłem „Bądź świadomym konsumentem”, więcej informacji na ten temat w raporcie ze spotkań: http://f5.pl/upload/content/old/uploaddocs/UOKiK_ raport_ostateczny.pdf (dostęp: 20.02.2017). 
w zakresie dostępu do informacji gospodarczej odbędzie się także z korzyścią dla przedsiębiorców. Nastąpi to, jeżeli będą oni tworzyć kompleksowe oferty dostosowane do potrzeb seniora, który rzetelnie informowany o szczegółach takich ofert, stanie się ich lojalnym i przyszłościowym klientem.

\section{Bibliografia}

Bałandynowicz-Panfil K., Interdyscyplinarne dylematy granic starszego wieku - wstep do rozważań nad wiekiem granicznym starszych konsumentów, „Acta Universitatis Lodziensis, Folia Oeconomica" 321 (3), 2016.

Gołaczyński J. [2009], Ustawa o świadczeniu ustug droga elektroniczną. Komentarz, Wolters Kluwer, Warszawa 2009, LEX.

Grochowski M., Obowiązi informacyjne w umowach z udziałem konsumentów a nadmierny formalizm prawa, [w:] Kierunki rozwoju europejskiego prawa prywatnego. Wpływ europejskiego prawa konsumenckiego na prawo krajowe, red. M. Jagielska, E Rottt-Pietrzyk, A. Wiewiórkowska-Domagalska, C.H. Beck, Warszawa 2012.

GUS, Sytuacja demograficzna osób starszych i konsekwencje starzenia się ludności Polski w świetle prognozy na lata 2014-2050, Warszawa 2014, s. 9, http://seniorzy.mcps.com.pl/sites/default/ files/Sytuacja_demograficzna.pdf.

Hładyszewski M., Umowy zawierane poza lokalem przedsiębiorstwa, [w:] Europejskie prawo konsumenckie a prawo polskie, red. E. Nowińska, P. Cybula, Kraków 2005.

Konarski X., Komentarz do ustawy o świadczeniu usług droga elektroniczna, Difin, Warszawa 2004.

Maciejewski M., Prawo informacji - zagadnienia ogólne, [w:] Prawo informacji. Prawo do informacji, red. W. Góralczyk, Wydawnictwo Wyższej Szkoły Przedsiębiorczości i Zarządzania im. Leona Koźmińskiego w Warszawie, Warszawa 2006.

Michalak A., Ustawa o przeciwdziałaniu nieuczciwym praktykom rynkowym. Komentarz, C.H. Beck, Warszawa 2008, Legalis.

Mielczarek J., Ustugi finansowe. Poradnik dla osób starszych, Warszawa 2010, https://www.rpo. gov.pl/sites/default/files/BIULETYN_RPO_Materialy_nr_73.pdf.

Mikłaszewicz P., Obowiazki informacyjne w umowach z udziałem konsumentów na tle prawa Unii Europejskiej, Wolters Kluwer, Warszawa 2008.

Pachucka-Smulska B., Ochrona konsumenta w prawie polskim i Unii Europejskiej, C.H. Beck, Warszawa 2013.

Skiba R., Główne problemy prawa do informacji w świetle prawa i standardów międzynarodowych, europejskich i wybranych państw Unii Europejskiej, C.H. Beck, Warszawa 2013.

Skorupka S., Anderska H., Łempicka Z., Mały słownik języka polskiego, Państwowe Wydawnictwo Naukowe, Warszawa 1968.

Sondel J., Słownik łacińsko-polski dla prawników i historyków, Universitas, Kraków 2009.

Stefanicki R., Informacje jako środek ochrony stabszej strony umowy w prawie wspólnotowym, „Studia Prawnicze" 2008, nr 1.

Szukalski P., Obszary zagrożenia praw osób starszych na rynku dóbr i ustug konsumpcyjnych, [w:] BIULETYN RPO materiały. Stan przestrzegania praw osób starszych w Polsce - analiza i rekomendacje działań, red. B. Szatur-Jaworska, Warszawa 2008.

Traple E., Prawo reklamy i promocji, Lexis Nexis, Warszawa 2007.

Wiewiórska-Domagalska A., Obowiązi informacyjne w prawie Unii Europejskiej i braki w zakresie ich implementacji do prawa polskiego, dodatek do MoPr. 2013, $\mathrm{nr} 21$.

Wojtaszek-Mik E., Informacja przedumowna w dyrektywie 2011/83/UE w sprawie praw konsumentów (problemy implementacyjne w prawie polskim), PPH kwiecień 2014. 


\section{Barriers in access to commercial information for elder consumers}

\section{Summary}

What results from the considerations above, as far as access to commercial information is concerned, elder consumers are in a far worse situation than the consumers in their prime. The current structure of information obligations on the grounds of consumer acts does not improve this situation at all. Therefore, it is necessary to change the legislative technique in the area of regulating information obligation by the means of introducing general norms as the counter-balance for casuistic regulations. It is also essential to take actions aiming to include seniors in the protection system through information and increased consumer awareness in the area of their rights. The improvement of access to commercial information must also be correlated with the prevention of the phenomenon of seniors' digital exclusion, as the Internet is the indispensable channel of conveying information on goods and services, as well as it is the place where consumers tend to purchase things more and more often. The improvement of the elderly people's situation in the area of access to commercial information will also be beneficial for entrepreneurs. It will happen if they create comprehensive offers suited to the senior's needs who, thoroughly informed about the details of such offers, will become their loyal and future customer. 